\title{
The evolution of sociality in rodents: a family affair
}

\section{Vladimir S. Gromov}

\begin{abstract}
Sociality means group-living. Among rodents, the most social species live in family groups that consist as a rule of not numerous individuals. Hence, the evolution of sociality among rodents is not a group-size evolution. A family-group lifestyle is associated with long-lasting pair bonds, participation of both parents in care of young, and cooperation in different activities. In family groups, cooperation starts from the very beginning when a breeding pair establishes, protects and marks its home range, digs burrows or constructs other shelters, and provides care-giving activities. Direct parental care (especially paternal care) by means of tactile stimulation of the young is suggested to promote long-lasting pair bonds and development of subsequent parental behaviors in sub-adult and adult males that is so typical of highly social rodent species. This phenomenon has an epigenetic nature and could be considered as 'stimulation of similar with the similar'. Cooperation extends and intensifies when the size of family groups increases as a result of delayed dispersal of the offspring. According to the proposed conceptual model, family groups could be formed under any ecological conditions, irrespective of predation pressure or resource distribution, given that mating pairs and, furthermore, family groups are more competitive due to cooperation than solitary conspecifics. The main driving forces are proximate mechanisms related to tactile stimulation of young individuals during their early postnatal development and cooperation. This conceptual model provides a better understanding of the evolution of sociality (i.e. transition to a family-group lifestyle) in different rodent taxa.
\end{abstract}

How to cite this article: Gromov V.S. 2017. The evolution of sociality in rodents: a family affair // Russian J. Theriol. Vol.16. No.1. P.47-65. doi: 10.15298/rusjtheriol.16.1.05

KEY WORDS: rodents, sociality, evolution, family-group lifestyle, parental behavior, cooperation, tactile stimulation, epigenetic theory.

Vladimir S. Gromov [vsgromov@mail.ru], A.N. Severtsov Institute of Ecology and Evolution, Russian Academy of Sciences, Leninsky pr. 33, Moscow 119071, Russia.

\section{Эволюция социальности у грызунов: переход к семейно-групповому образу жизни}

\section{B.C. Громов}

РЕЗЮМЕ. Социальность означает групповой образ жизни. Среди грызунов наиболее социальные виды живут семейными группами, в состав которых входит относительно небольшое число особей. Семейно-групповой образ жизни связан с укреплением парных связей, участием обоих родителей в воспитании потомства и кооперацией в различных видах деятельности. Кооперация проявляется с самого начала, когда семейная пара совместно осваивает участок обитания, охраняет и маркирует его, роет подземные коммуникации, сооружает гнездо и заботится о потомстве. Родительское поведение в виде тактильной стимуляции детенышей имеет особое значение, поскольку способствует укреплению парных связей и стимулирует соответствующую заботу о детенышах у полувзрослых особей и самцов, что наиболее характерно для социальных видов грызунов. Этот феномен имеет эпигенетическую природу и может характеризоваться как «стимуляция подобного подобным». С появлением в семейных группах молодняка, расселение которого задерживается, кооперация приобретает наиболее широкие масштабы. Согласно предлагаемой концепции, семейные группы у грызунов формируются в любых экологических условиях, независимо от распределения кормовых ресурсов и пресса хищников, если особи, объединившиеся в семейные пары, оказываются, благодаря кооперации, более конкурентоспособными в сравнении с особями-одиночками. Проксимальные механизмы, связанные с укреплением парных связей и стимуляцией родительского поведения благодаря тактильной стимуляцией детенышей, вкупе с кооперацией можно рассматривать в качестве основных факторов эволюции социальности у грызунов. Предлагаемая концепция обеспечивает лучшее понимание процессов, связанных с эволюцией социальности (т.е. переходом к семейно-групповому образу жизни) в разных таксонах грызунов.

КЛЮЧЕВЫЕ СЛОВА: грызуны, эволюция, социальность, семейно-групповой образ жизни, кооперация, тактильная стимуляция, эпигенетическая теория. 


\section{Introduction}

During the last 50 years considerable attention has been given to the relation between social organization of mammals, their diet and ranging, and their ecological environments (Crook, 1970a, 1970b; Eisenberg et al., 1972; Alexander, 1974; Barash, 1974; Clutton-Brock, 1974; Hladik, 1975; Hoogland, 1981; Armitage, 1981, 1999, 2007; Schaik \& van Hooff 1983; Carr \& Macdonald, 1986; Terborgh \& Janson 1986; Macdonald \& Carr, 1989; Burda, 1990; Janson, 1992; Faulkes et al., 1997; Bennett \& Faulkes, 2000; Ebensperger \& Cofré, 2001; Hare \& Murie, 2007; Lacey \& Sherman, 2007). Most of this work has been concerned with finding correlations between diet, ranging, and group size of different mammalian species. According to the generally accepted socioecological model (Crook, 1970a, b; Alexander, 1974), group size is a core trait defining social systems, so understanding group-size evolution is suggested to be critical to understanding the evolution of sociality, or group-living (Pollard \& Blumstein, 2008). Such a view is traditional and based primarily on comparative studies of social organization in birds, primates and ungulates whose individuals may aggregate in large flocks, groups and herds which are referred to as most social (Crook, 1970a, b; Jarman, 1974; Terborgh \& Janson, 1986).

As for rodents, their social organizations range from species whose young individuals disperse after weaning and live as more or less solitary dwellers, to species whose individuals exhibit delayed dispersal and in which overlapping generations share a home range and interact amicably. Besides, rodent species can be placed objectively along a continuum of social complexity (Blumstein \& Armitage, 1997, 1998), and such a criterion of sociality as group size is not quite appropriate for rodents (Burda et al., 2000; Gromov, 2008, 2011a) because the most complicated social structure is characteristic of those rodent species that form rather small family groups, with the only exception - the naked mole-rat, Heterocephalus glaber Rüppell, 1842 (Jarvis et al., 1994). In other words, a core trait defining social systems and social complexity in rodents is not group size, but group structure or group composition (Gromov, 2008, 2011a).

In this article, I present a short review of the past and current knowledge of the social organization of rodent communities and critically evaluate different conceptual approaches to their sociality. I intend to show that the selective pressures favoring sociality in rodents are not well understood to date. I suppose that such features as group composition and its structure, instead of group size, are much more important as an indicator of sociality in rodents and for understanding of the evolutionary processes by which groups form. And I will try to show that the main factors promoting the evolution of sociality among rodents are cooperation and proximate mechanisms related to tactile stimulation of young individuals during their early postnatal development.

Rodent social units and their classification in relation to sociality

Classification of rodent social units should be based on the analysis of spatial relationships, mating strategies, and group composition instead of group size during the breeding season. Considering spatial relationships and group structure, it is important to realize that rodents are primarily sedentary animals, and every adult individual possesses a home range used for basic requirements: foraging, digging of burrows or construction of other shelters to avoid predators and reproduce, interaction with conspecifics, etc. Formation of aggregations and cohesive groups in rodent populations, with rare exceptions, results from more or less tolerant interactions between conspecifics and subsequent overlap of their home ranges. Relevant social organizations of rodents may be classified as follows:

\section{Organizations characterized by relatively sol- itary behavior}

Solitary dwellers, i.e., species whose adults, especially of the same sex, use primarily exclusive home ranges, and thus could be considered as conditionally nonsocial species like many hamsters, ground squirrels, voles and gerbils (Gromov, 2008, 2011a). In some species belonging to this category, for instance, in the tamarisk gerbil, Meriones tamariscinus (Pallas, 1773), males form temporal and unstable aggregations in the vicinity of ranges of receptive females during the reproductive season (Gromov, 2011a, b). Relationships based on territoriality among same-sex individuals along with dominance hierarchy among males competing for females in temporal aggregations, weak pair bonds and mutual intolerance among adults, as well as promiscuous mating, sole maternal care of young and early offspring dispersal are common features of the spatial structure and social organization of this category of rodent species.

\section{Organizations characterized by gregarious behavior}

Partially overlapping home ranges of adults reflect formation of relatively stable multi-male-multi-female breeding colonies (they have also been called associations or aggregations) in species like, for example, the bank vole, Clethrionomys glareolus (Schreber, 1780), the wood mouse, Apodemus sylvaticus (Linnaeus, 1758), the midday gerbil, Meriones meridianus (Pallas, 1773), or Wagner's gerbil, Dipodillus dasyurus (Wagner, 1842) (Bujalska \& Saitho, 2000; Gromov et al., 2000; Gromov, 2008, 2011a), as well as winter aggregations in some voles, mice and gerbils (Gromov, 2008, 2011a). During the breeding season, adult females tend to maintain exclusive and protected home ranges; adult males occupy much larger and unprotected home ranges located corresponding to the location of the females' 
ranges; mature males form clans with overlapping home ranges, and males belonging to the clan and competing for reproducing females establish a dominance hierarchy. Primarily promiscuous mating, relatively weak pair bonds, sole maternal care, early offspring dispersal, and female natal philopatry are typical of many rodent species belonging to this category. In the winter aggregations, several individuals of both sexes and of different ages, including unrelated ones, may occupy a common home range or even share a burrow to survive the severe season.

Perhaps, the only rodent species that is characterized by mobile aggregations of individuals is the capybara, Hydrochoerus hydrochaeris Linnaeus, 1766 (Macdonald, 1981). Capybaras may live solitarily or in multi-male - multi-female groups numbering up to 50 or even more individuals. Capybara group sizes were found to vary from habitat to habitat in a way which seemed explicable by the pattern of the dwindling water supply.

A total overlap of individual home ranges of several unrelated adults seems to be impossible for rodents, with the exception of formation of winter aggregations in some gregarious species, and further grouping that leads to a higher social complexity actually means formation of breeding pairs and, subsequently, due to reproduction and delayed offspring dispersal, restricted and extended family groups (Gromov, 2008, 2011a).

\section{Organizations characterized by a family- group lifestyle}

Spatially, members of a family group exhibit considerable overlap, including sharing a nest burrow or other shelter. Behaviorally, interactions within family groups markedly differ from those between groups with the former being to include affiliative, cooperative, and nepotistic activities. I distinguish between (a) restricted family groups consisting of a breeding pair and their offspring that disperse early (in a relatively short period of time after weaning) and (b) extended family groups with long-lasting social bonds between parents and their offspring, where adult founders of the group coexist with two or more litters and even generations of young (e.g., in Marmota spp.) exhibiting delayed dispersal. In extended family groups, more than one adult individual of either one or both sexes can breed. In extended polygynous family groups, reproducing females can occupy separated home ranges or share one nest burrow.

Each family group usually occupies a defended territory that provides almost total food security for the pair of adults and their offspring in monogamous families, or a complex and also protected home range encompassing breeding territories of two or more reproducing females in extended family groups. Long-term pair bonds, biparental care, delayed offspring dispersal, cooperation in different activities, a complicated social organization related to age-based hierarchy, dif- ferentiation of behavioral roles, and suppression of reproduction in offspring are characteristic of many rodent species with family-group lifestyle, for example, beavers (Castor canadensis Kuhl, 1820, C. fiber Linnaeus, 1758), the Olympic marmot, Marmota olympus Merriam, 1898, Eurasian marmots (Marmota bobac (Müller, 1776), M. caligata Eschscholtz, 1829, M. caudata Geoffroy, 1844, M. marmota Linnaeus, 1758, M. sibirica Radde, 1862), the musk-rat, Ondatra zibethica (Linnaeus, 1766), the tuco-tuco, Ctenomys sociabilis Pearson et Christie, 1985, the great gerbil, Rhombomys opimus (Lichtenstein, 1823), the Mongolian gerbil, Meriones unguiculatus Milne-Edwards, 1867, the Brandt's vole, Lasiopodomys brandtii (Radde, 1861), the mandarin vole, L. mandarinus (Milne-Edwards, 1871), and some other highly social rodents (Marinelli \& Messier, 1995; Lacey, 2004; Armitage, 2007; Busher, 2007; Gromov, 2008, 2011a), as well as the naked mole-rat, H. glaber, and the Damaraland mole-rat, Cryptomys damarensis (Ogilby, 1838), regarded as the most social (eusocial) species (Jarvis, 1981; Bennett \& Faulkes, 2000).

Breeding within family groups is commonly restricted to one female and one male (a monogamous family). However, in female-biased populations of the yellow-bellied marmot, Marmota flaviventris Audubon et Bachman, 1841 (Armitage, 1962), prairie dogs, Cynomys spp. (Travis \& Slobodchikoff 1993), beavers (Busher, 2007), musk-rats (Marinelli \& Messier, 1995), tuco-tucos (Lacey et al., 1997), prairie voles, Microtus ochrogaster Wagner, 1842 (Roberts et al., 1998a, b), Brandt's voles (Zhang \& Zhong, 1981), Mongolian gerbils (Ågren et al., 1989a; Gromov, 2008, 2011a, b), great gerbils (Rogovin et al., 2003), and some other species, family groups include two or more reproducing females (polygynous families). Besides, in the case of the naked mole-rat, there are polyandrous families with two or three males mating with one female (Jarvis et al., 1994).

Thus, the evolution of group-living among rodents proceeds in two main directions: formation of aggregations (relatively stable multi-male-multi-female breeding colonies) and formation of family groups. But it is the latter that is characterized by the most complicated social structure, especially like that in so-called eusocial rodents - H. glaber, C. damarensis, Cryptomys hottentotus (Lesson, 1826) or Fukomys mechowi (Peters, 1881) (Burda, 1990; Jarvis et al., 1994; Burda et al., 2000; Bennett \& Faulkes, 2000; Molteno \& Bennett, 2002). Eusociality among rodents generally means overlap of generations, cooperative rearing of young and non-reproducing working caste. Eusocial rodents live in social groups composed of close kin, within which breeding is restricted to one female and one to three males. In other words, reproduction is limited to a small subset of behaviorally dominant group members while subordinates serve as nonbreeding alloparents. This reproductive skew, or asymmetry in reproductive success, can be generated by the inhibition of either 
reproductive physiology or reproductive behavior in subordinates

As a generalization, the evolution of sociality among rodents actually means the transition towards a familygroup lifestyle. Family groups especially that ones with complicated social structure form due to pair bonding, delayed offspring dispersal and continued association of kin, which facilitates cooperation and social interactions. Hence, the most important point to understanding the evolution of sociality among rodents is determination of causes and factors related to pair bonding and biparental care because formation of any family groups starts from breeding pairs that cooperatively raise their offspring.

\section{Conceptual approaches to sociality in ro-} dents

Studies of social species have traditionally focused on identifying benefits intrinsic to group-living, such as increased predator protection, increased access to limited resources, and improved foraging due to cooperation among mates (Alexander, 1974). To account for formation of aggregations (groups) in different rodent taxa, a few socioecological conceptual models have been proposed.

One of them, the 'resource dispersion hypothesis' $(\mathrm{RDH})$, describes ecological circumstances whereby groups could evolve (Slobodchikoff, 1984; Ostfeld, 1990): when resources are patchy, females should form groups to defend the patches, whereas when resources are uniform, females should not clump; males should associate with a group of females (polygyny), when resources are patchy, but only with a single female (monogamy), when resources are uniform. Data of some field and experimental studies are partially consistent with the RDH. For instance, altering a habitat to a more uniform distribution of food resources has resulted in a greater number of monogamous associations versus polygynous in two populations of Gunnison's prairie dogs, Cynomys gunnisoni (Baird, 1855) (Travis \& Slobodchikoff, 1993). Another example is the prairie vole. Field studies carried out in two populations of this species in Illinois and Kansas (Roberts et al., 1998a, b) indicated that ecological variation might be a major cause of intra-specific variation in group structure. Prairie voles from a population in Illinois are monogamous cooperative breeders living in extended families formed from a closely bonded breeding pair that maintains a common territory (Carter et al., 1995; Carter \& Roberts, 1997). In contrast, prairie voles from the population in Kansas are not monogamous, and home ranges of the males overlap those of several females (Danielson \& Gaines, 1987; Getz et al., 1993). In Illinois, prairie voles occupy a moist habitat, typically abundant with preferred food plants (Getz, 1985). In contrast, prairie voles in Kansas occupy a drier habitat of grasses (Getz et al., 1981; Foster \& Gaines, 1991). It is suggested that under conditions of scarce food resources and ephemeral moisture in the Kansas population, opportunities might exist to acquire independent territory as well as dispersal, and independent breeding might be favored over philopatry. It remains, however, unclear whether prairie voles from both populations possess a monogamous mating system, although this species usually is referred to as typically monogamous (Carter \& Getz, 1993).

Habitat conditions of scarce food resources combined with ephemeral moisture, similar to those of Kansas, are shown to result in formation of monogamous breeding pairs in the populations of other microtine species, the social vole, Microtus socialis (Pallas, 1773), in the Kalmykia desert (Kasatkin, 2002; Gromov, 2011a). Comparing these two species of genus Microtus (M. ochrogaster and M. socialis), we found that at least two of their populations are very similar in terms of use of space, pair bonding, breeding structure, mating system and parental care (Getz et al., 1981, 1993; McGuire \& Novak, 1984; Kasatkin, 2002; Gromov, 2011a), but exist in different habitats in terms of abundance of food resources as well as moisture conditions. Hence, the RDH might account for some intraspecific differences in rodent social systems resulting from various environmental conditions, but does not explain how identical social systems evolve in different habitats, or how different social systems evolve under similar environmental conditions. Moreover, Carter and Getz (1993) believe that monogamy in prairie voles evolved in the past when food was not plentiful. But, if so, it is unclear why the RDH is based on evaluation and comparison of the current environmental and habitat conditions.

Besides, the effects related to distribution of food resources are revealed in the species with a familygroup lifestyle only (M. ochrogaster, C. gunnisoni), and no basic change of their social organization was found in either case. As for solitary foragers like the tamarisk gerbil, M. tamariscinus or the fat sand rat, Psammomys obesus Cretzschmar, 1828, uneven (patchy) distribution of food resources was found not to promote formation of polygynous social units (Daly \& Daly, 1974; Gromov, 2001, 2008, 2011b). Thus, the RDH does not really explain the effect of habitat conditions on the evolution of different social systems in rodent populations.

Among other conceptual models of rodent sociality related to the effect of resource distribution, the 'aridity-food-distribution hypothesis' (AFDH) merits special attention. According to the AFDH, social evolution is correlated with a harsh environment resulting in formation of the most complicated social organization described in subterranean African mole-rats whose groups are typically extended families (Jarvis et al., 1994; Faulkes et al., 1997; Lacey \& Sherman, 2007). The AFDH proposes that the energetic cost of burrowing through hard soil to locate patchily distributed but locally abundant food resources is the primary selective factor favoring group-living. By living together and 
working cooperatively to excavate tunnels, the animals are able to locate sufficient food resources to survive until the next wet season.

The AFDH seems to be quite consistent with behavioral and ecological patterns among African mole-rats, but it does not explain sociality among semi-subterranean or surface-dwelling rodents. Moreover, Burda (1990) argued that eusociality of the naked mole-rat is not qualitatively unique and has not evolved as an immediate response to aridity and dispersed food resources as generally considered. He suggested that low postnatal developmental rates are a cause rather than consequence of eusociality in subterranean hystricognath rodents (Burda, 1990; Burda et al., 2000). In addition, I'd like to note that the evolution of eusociality could not be explained by the effect of ecological factors only (without impact of cooperation). Besides, neither the RDH nor the AFRH account for how external (ecological) factors promote pair bonding and inhibition of mutual aggressiveness (the last is typical of solitary dwellers) as well as stimulation of parental care in males that is characteristic of rodents with a familygroup lifestyle.

As for other external factors, predation is also frequently invoked as a selective pressure favoring group living, especially among ground-dwelling sciurids (Hoogland, 1981; Krause \& Ruxton, 2002). Predation risk is suggested to influence the size of foraging groups, and these groups in turn affect the ability of animals to detect predators (Blumstein et al., 1997; Sherman, 1997; Ebensperger \& Wallem, 2002; Ebensperger et al., 2006). In other words, predation is believed to predispose animals to live in social groups. However, predation on ground squirrels may be intense, and some of the heaviest losses to predation occur in the spermophiles that nevertheless live individually within aggregations. If predation was the selective force causing sociality, one could expect these species to be more social than they are (Armitage, 1981). The same is true in relation to any other rodent taxa. It is not proved that predation pressure in populations of solitary dwellers is significantly lower than in populations of social species. Moreover, predation pressure may prevent formation of larger groups in rodent populations. For instance, disappearance of whole groups in the prairie vole populations, presumably due to predation by weasels, was shown to be associated with relative group size such that the largest groups were more likely to disappear (McGuire et al., 2002). Similar results were obtained in a study of meadow voles, Microtus pennsylvanicus Ord, 1815 (Madison et al., 1984). Besides, the socalled 'many eyes effect' that is proposed to promote group formation in animal communities (Pulliam, 1973) was found to be equally exhibited by solitary dwellers and species living in family groups (Heaney \& Thorington, 1978; Hoogland, 1979; Carey \& Moore, 1986; Blumstein, 1996; Jêdrzejewski et al., 1992; Ebensperger \& Wallem, 2002; Ebensperger et al., 2012). As for other well-known anti-predator tactics related to 'dilu- tion effect' or 'selfish herd effect', these do not work in rodents: when attacked by a predator, any individual (with very rare exceptions like porcupines, Hystrix spp., or capybaras) looks for the nearest burrow or some other shelter to flee from danger. Alarm calls or socalled group effect in itself can not serve as convincing evidence that predation favors group living because both the appropriate acoustic signalization and 'group effect' are well developed in different rodent species irrespective of their sociality. In other words, predation pressure could not be considered as an essential selective factor promoting group formation, especially family-group lifestyle, in rodent populations.

In many ground-dwelling sciurids, large body size and hibernation are two critical features from which their sociality is suggested to evolve. A short growing season requires the retention of offspring in their natal group for one or more additional years to reach maturity (Barash, 1974; Armitage, 1981, 1999). For example, Olympic marmots achieve less than $25 \%$ of their adult body mass during the year of birth, and the young need to remain with their mothers. As yearlings, Olympic marmots are still only 30\% mature and, accordingly, they remain closely associated with their mothers until they are 2 years old. At this point, having achieved $70 \%$ of adult body mass, the Olympic marmots finally disperse and bear their first progeny the following (their third) year (Barash, 1974). Similar results concerning offspring development are obtained for the alpine marmot, M. marmota (Arnold, 1990a). Prolonged toleration of offspring was hypothesized to be a means of preventing dispersal of undersized young (Barash, 1974) or continued parental investment in marmots (Armitage, 1981, 2007). Social thermoregulation that is best documented in the alpine marmot (Arnold, 1990a, b, 1993) has also been found to increase the survival of juveniles and their parents, and hence also plays an important role in the evolution of sociality among these sciurid rodents (Armitage, 2007). It is likely that such an intrinsic factor as long developmental time as well as benefits from the subordinates' presence for rearing young could account for the evolution of sociality among other larger-sized rodents like beavers, porcupines, musk-rats, etc.

Some conceptual models of the evolution of sociality among rodents are related to the consequences of female philopatry. In some rodent species, there are female groups that result from retention of female offspring on natal territories or entry of new females onto territories of established males (Nel, 1975; Armitage, 1981; Solomon, 2003; Nunes, 2007; Solomon \& Keane, 2007). Relevant examples were found in different rodent taxa including both social and non-social species like ground squirrels that live individually (Vestal \& McCarley, 1984; Yensen \& Sherman, 2003). It should be especially noted that quite different processes formation of aggregations and formation of family groups - are mixed up in many of these hypotheses, and such a discrepancy prevents understanding the role 
of philopatry in the evolution of sociality among rodents. One needs to realize that philopatry does not promote formation of family groups on the first stage because mating partners are not typically close kin. But subsequently, both restricted and extended family groups result from natal philopatry, and not due to female philopatry only, but due to delayed dispersion of young individuals of both sexes. Formation of extended family groups in some so-called communal-nesting rodents (e.g. L. brandtii, see Gromov, 2008) may occur due to female philopatry (usually because of retention and reproduction of female offspring on a natal territory) but this is a relatively rare case in rodent populations. As for clustered matrilineal groups, these are more typical for gregarious rodent species, but not for those living in family groups (Holmes \& Mateo, 2007; Waterman, 2007).

Lacey and Sherman (2007) proposed an integrated three-dimensional ecological model for sociality in rodents. This model was derived from comparative analyses of the social subterranean species, but the authors suppose that it may be applicable to surface-dwelling rodents as well. One axis of this model represents access to most important food resources, another one is related to predation pressure, and the third one incorporates benefits of cooperation. According to this model, conspecifics may be required to live together in order to have access to limited, patchily distributed resources. Predation is also assumed as a selective pressure favoring group living, and despite the lack of quantitative information regarding differences in predation on solitary versus social species, the authors believe that predation is an important factor that should be included in the proposed model. As for the third axis (i.e. cooperation), it appears to differ from previous two ones in that it represents a consequence rather than a cause of group living. But cooperation may be supposed to function as a form of group augmentation (Kokko et al., 2001) that contributes significantly to the maintenance of sociality. At least the extent of cooperation among group mates provides an important basis for comparing different social systems (Lacey \& Sherman, 2007). Although the proposed model does not explain how such external factors as distribution of food resources and predation promote pair bonding, it is fairly true in that sociality likely reflects the combined effects of multiple environmental factors as well as the important role of cooperation in formation of family groups.

To summarize this section, one can conclude that selective pressures favoring sociality in rodents are not well understood so far. At least convincing evidence that predation pressure or a particular mode of distribution of food resources promote pair bonding and biparental care ensuring transition to family-group lifestyle is absent. It seems that a set of the ecological conditions dictating the necessity of a family-group lifestyle is unique for each relevant rodent species, and there are no universal rules explaining the influence of external factors on species-specific social organization. Afore- mentioned conceptual models might possibly account for formation of aggregations in rodent populations or intra-specific variation in composition of family groups, like in Gunnison's prairie dog or the prairie vole, but do not generally explain the evolution of family-group lifestyle among rodents. Therefore, a new conceptual model needs to be developed to account for the way in which, through evolution, species features and environmental forces interact to shape social structure of rodent societies. In this concept, from my point of view, the main part should be assigned to cooperation.

\section{Cooperation as a driving force of the evolu- tion of sociality in rodents}

Crook (1970b) as one of the founders of the socioecological concept claimed that social selection is a major source of biological modification, and social forces alone may play a greater role in the determination of social behavior. Continuing with this line of thought, one can suggest that cooperation is one of such social forces playing an essential role in the evolution of sociality among rodents. Incidentally, the AFRH would not explain the evolution of eusociality among African mole-rats without the involvement of cooperation.

Cooperation is widespread in rodent communities. Moreover, there is no social rodent species that does not exhibit cooperation (Ågren et al., 1989b; Arnold, 1990a, b; Taber \& Macdonald, 1992; Corbet \& van Aarde, 1996; Faulkes et al., 1997; Armitage, 1999; Ebensperger et al., 2002; Busher, 2007; Lacey \& Ebensperger, 2007; Nunes, 2007; Gromov, 2008, 2011a; Hayes et al., 2009). In family groups, cooperation starts from the beginning, when a mating pair establishes, maintains and marks its home range, digs burrows or constructs other shelters, and then takes care of the offspring. That is why cooperation is suggested to be the main driving factor that promotes the evolution of sociality among rodents. According to this concept, family groups could be formed under any ecological conditions, irrespective of predation pressure or resource distribution, given that solitary foragers would be less competitive than mating pairs and, furthermore, family groups, in which, due to cooperation, the efforts of many individuals are successfully combined to construct complex burrow systems, hoard food stores, defend and mark the territories, and take care of young. It is a complicated family-group social organization suppressing intra-specific aggression or, at least, minimizing its negative effects and promoting social bonds, which is necessary for successful cooperation. Biparental care seems to be the commonest and most important form of cooperation among rodents living in family groups (Gromov, 2011a, c, d). Along with biparental care, many rodent species exhibit another essential form of cooperation - alloparenting, when the remaining group members assist the breeders in rearing young. Alloparenting is a form of reproductive altruism that is 
found in many rodents with extended family groups, for instance, in beavers, naked mole-rats, Mongolian and great gerbils, prairie voles, Brandt's voles, mandarin voles (Patenaude, 1983; French, 1994; Jarvis et al., 1994; Wang \& Insel, 1996; Roberts et al., 1998c; Clark \& Galef, 2000; Gromov, 2011a). Alloparental care via supplemental tactile stimulation of the young appears to play the most essential role in formation and maintenance of social bonds and a high degree of group cohesion (Gromov, 2011a).

Females gain the most benefits from pair bonding, especially due to cooperation with male mates. Once males and females live together as breeding pairs, further evolution of social behavior may enhance the original advantage of group living. Formation of family groups promotes complication of the social organization that, in turn, results in extending and intensifying cooperation when the size of family groups increases due to delayed offspring dispersal; concurrently, the family group members achieve greater fitness due to the cooperation and more successfully compete with solitary conspecifics. Thus, cooperation should be considered the core trait of the family-group lifestyle, and biparental care along with alloparenting play a key role among other cooperative behaviors due to which members of the family group gain essential benefits.

\section{Behavioral effects of tactile stimulation}

Normally, events within the nest and reactions of the pups to occurrences within the nest provide a rich stimulus environment that shapes early development and later social behavior (Fleming et al., 1999). One would expect somatic sensory inputs (tactile stimulation) to play an essential role in the regulation of parental responsiveness, since females as well as males of many social rodents spend much time in physical contact with their offspring. In particular, adult laboratory rats that were exposed to either complete maternal deprivation as neonates or to prolonged periods of maternal separation as neonates showed reductions in maternal behavior, which included decreases in nursing behavior and maternal licking and grooming that in turn resulted in a deficit of tactile stimulation of their pups (Fleming \& Luebke, 1981; Fleming \& Sarker, 1990; Fleming et al., 2002). It is also proved that the degree of licking and grooming that a mother rat displays towards her pups influences the development of the same parental responsiveness in her offspring (Meaney \& Champagne, 2000).

Another recent study assessed the effects of complete maternal deprivation and the 'replacement' of maternal behaviors by the addition of simulated maternal-licking (with a soft paint brush) on the development of adult maternal behaviors (Gonzalez et al., 2001). The results indicated that how infants were reared affected both later maternal and emotional behavior. In particular, artificially reared rat females showed reduced levels of retrieving, licking, and crouching over pups; in addition, they spent less time in the nest. But artificially reared neonates that were provided with additional tactile stimulation that mimicked the effects of mothers' licking have shown patterns of behavior more similar to mother-reared females. Thus, maternal behavior related to tactile stimulation of pups serves to provide the offspring with experiences that promote their behavioral development and the appropriate expression of their parental behavior when they grow up.

Although experimental studies on rodent parental behaviors have primarily focused on the interactions between mothers and their offspring, with little research directed at understanding paternal behavior, recent findings suggest that the tactile stimulation provided by paternal huddling over and licking (grooming) pups may result in similar changes in the subsequent behavior of young. Moreover, these effects might be expected in the infants of both sexes. In particular, experiments with cross-fostering highlight the role of tactile stimulation in development of parental responsiveness and pair bonding. For example, a study carried out by McGuire (1988) has shown that the young of the meadow vole (a species with promiscuous mating and primarily sole maternal care) reared by parents of the prairie vole (a species with biparental care) received more parental contacts than pups fostered to meadowvole parents. When tested in adulthood, cross-fostered males often entered the natal nest and engaged in more pup contact behavior than in-fostered males, in that number brooding and grooming pup (the last behavior is not typical of the meadow vole males). In terms of sociality, experimental groups of the meadow vole, in which males exhibited paternal care, could be regarded as more social ones.

Experiments with the Mongolian gerbil and the common vole, Microtus arvalis (Pallas, 1778) (Gromov, 2009, 2013) showed that father-deprived males exhibited a lower rate of subsequent parental responsiveness related to nest attendance and grooming pups. Besides, father-deprived males groomed their female mates significantly less frequently than did biparentally raised males. In terms of sociality, the experimental groups of these species, in which both males and females exhibited lower rates of pair-bonding and parental behaviors, could be considered as less social ones.

These findings suggest that pair bonding and development of parental behavior, especially paternal responsiveness, are subject to influence by characteristics of the early environment. It is evident that young males can 'inherit' to some extent the stereotype of parental behavior of their sires (McGuire, 1988; Roberts et al., 1998b), and father-deprived males care for their own progeny to a lesser degree than males that grew in biparental families (Gromov, 2009, 2013). Similar alteration of parental responsiveness occurring both in males and females become fixed and intensified within generations.

The role of tactile stimulation in the formation of complicated social organization of rodents has almost 
not been studied. Research carried out on a number of species with a family-group lifestyle (Elwood, 1975, 1979; McGuire \& Novak, 1984; Solomon, 1993; Clark et al., 1997; Smorkatcheva, 2003; Gromov, 2011a, c, d) indicates that infants reared by two parents receive additional tactile stimulation from their sires, whereas the offspring nourished by the female only in solitary dwellers are devoid of such extra stimulation. Bearing in mind the results of the experiments on artificial rearing and cross-fostering in rats and prairie voles (McGuire, 1988; Roberts et al., 1998b; Gonzalez et al., 2001), as well as the experiments with Mongolian gerbils and common voles (Gromov, 2009, 2013), one may conclude that participation of males in rearing their offspring is the most important factor of subsequent development of the behavioral stereotype of 'attentive father and mating partner' that is so typical of many rodent species with a family-group lifestyle. Moreover, additional tactile stimulation of infants promotes reinforcement of social bonds and establishment of cohesive behavioral interactions in family groups.

\section{A new conceptual approach to the evolu- tion of sociality in rodents}

Studies on rodent parental behavior have shown that direct parental care related to tactile stimulation of infants is one of the physiological mechanisms promoting long-term pair bonds and development of subsequent parental behavior, especially paternal care (Gromov, 2009, 2011a, d, 2012). This phenomenon has an epigenetic nature and could be considered as 'stimulation of similar with the similar'. One can suppose that biparental care and alloparenting provide additional tactile stimulation of infants and thus play an essential role in the evolution of sociality among rodents. The significance of such a proximate mechanism is so far underestimated.

There is no need to consider here the effect of paternal care on the general fitness and survival of offspring because experimental studies on different rodent species provide conflicting information related to the effect of the presence of the sires on the development and survival of their offspring. For example, male parental investment was found to increase pup survival in the California mouse (Gubernick et al., 1993; Gubernick \& Teferi, 2000) and the Mongolian gerbil (Gerling \& Yahr, 1979), as well as to accelerate pup development in the prairie vole (Wang \& Novak, 1992, 1994) and the meadow vole (Storey \& Snow, 1987), but no effect was revealed in other species or under different environmental conditions (Elwood \& Broom, 1978; Priestnall \& Young, 1978; Wuensch, 1985; Shilton \& Brooks, 1989).

In species with a family-group lifestyle, a higher parental responsiveness is primarily provided by sires. Of course, they do not nurse pups and commonly yield to dams considerably in the time spent on grooming pups. However, direct paternal care in the form of tactile stimulation of infants is of exclusive importance for pair bonding, and is likely related to enhancing juvenile philopatry, especially of young females. In many rodent species with a family-group lifestyle, extended families that comprise several females seem to be formed due to such a natal philopatry (Gromov, 2008).

Regardless of the causes of philopatry, individuals remaining in native family groups have to differ behaviorally and socially from those inclined to disperse, and their behavior should be adaptive for the coexistence of close kin within strongly cohesive family group. The most common features of this behavior include decreased aggressiveness and increased tolerance towards group members as well as parental responsiveness to infants (alloparental care) exhibited by not only young or subadult females, but males as well.

The main question arises on how this behavior could be stimulated and developed, and what factors induce this process. The experimental studies have convincingly shown that the primary factors affecting the development of tolerant behavior are internal (hormonal and neurobiological) ones associated with the early social environment, rather than external (ecological) factors (see reviews in Gromov, 2011a, 2012). In turn, the early social environment is primarily determined by whether females take care of the young alone, as is typical of solitary living and gregarious rodent species, or if both parents are involved in this process, as is characteristic of not numerous social rodents.

The role of tactile stimulation in the formation of complex social systems remains poorly studied. Tactile stimulation is not the only proximate mechanism, through which a higher sociality could be evolved, but it is this kind of stimulation that produces long-lasting changes in the brain involved in development, stimulation and maintenance of parental and pair-bonding behaviors (see reviews in Gromov, 2011a, 2012). A deficiency in tactile stimulation at the early stages of postnatal development brings about more aggressive adult individuals that are emotionally unstable in their interactions with conspecifics, including their mates (UvnäsMoberg, 1998). Such a behavioral alteration negatively affects intra-family relationships, because sexual partners are prone to avoid each other and to be less parental as well. Relevant social relationships are described, for example, in marmots (in particular, Marmota marmota, M. olympus, M. sibirica, M. menzbieri Kashkarov, 1925). It is well-known that lactating females of these species of marmots respond aggressively to their mates, and young individuals grow without paternal care during the first several weeks of their life. Adult males have the opportunity to contact with offspring after their appearance on the surface (after weaning), and many of these interactions are often agonistic (Barash, 1973, 1976; Suntsov, 1981; Mashkin, 1983). By the way, grooming is rarely observed in marmot family groups (Suntsov, 1981; Mashkin, 1983). Such features of male behavior could be explained by the 
lack of direct paternal care, especially of tactile stimulation (licking and grooming), during yearly postnatal development, so subsequently adult males do not take care of their young and live separately (occupying individual burrows) within family-group home ranges.

Persistent pair bonds and participation of males in care-giving activities (with some exceptions like in marmots) are characteristic of highly social rodent species including so-called eusocial ones. In the naked mole-rat, the function of two to three adult males within a complex family group is exclusively confined to mating with the only reproducing female and taking care of numerous litters (Jarvis, 1981; Jarvis et al., 1994). Subadult individuals in the naked mole-rat, as well as in many other social rodent species, also take care of the young, including licking, grooming and huddling (Patenaude, 1983; French, 1994; Roberts et al., 1998c; Clark \& Galef, 2000; Jarvis et al., 1994; Wang \& Insel, 1996; Gromov, 2011a). This behavior is likely to be formed in juvenile individuals due to additional tactile stimulation by parents, as well as by older siblings. Anyway, as has been demonstrated by Wang and Insel (1996), prairie vole pups that received care from both parents and assisting kin from the older litters later displayed more active parental care compared to individuals from the litters reared by the parents alone.

In species with a family-group lifestyle, the total level of parental care is considerably higher when compared with solitary dwellers or gregarious species (Gromov, 2011a, c). The interspecific variation in the expression of parental behavior in females, although fairly noticeable, is still less pronounced than that one in males. One can assume that the paternal contribution to the behavioral development of juveniles, especially of the same sex, is an important factor determining subsequently the strength of pair bonds as well as the total level of parental responsiveness, and, finally, the complexity of the social organization as a whole.

Considering the phenomenon under study, I would like to note that there is no definite or 'standard' level of sociality that would be characteristic of any rodent species. Experimental studies show that a relatively high degree of intraspecific variability is typical of both pair-bonding and parental behaviors (McGuire, 1997; Gromov, 2011a, c). It means that within populations of any gregarious, polygamous or monogamous rodent species there are breeding pairs and family groups that could be regarded as more social and less social. This intraspecific variation in social attachment between members of breeding units, as well as in parental responsiveness, could be explained particularly by the effect of the early social environment. In other words, it depends on the degree of participation of adult males in care-giving activities. Variation in parental care, especially paternal one, can serve as the basis for nongenomic transmission of individual differences in parental responsiveness and other social behaviors across generations (Gromov, 2009, 2011a, 2012, 2013).
These findings suggest the following conclusions. First, the intraspecific variation in parental behavior, which appears even under laboratory conditions, is controlled by factors not directly associated with the physical environment. Second, the major factors that influence pair-bonding and parental behaviors are social and (indirectly) physiological factors rather than ecological ones. These factors determine involvement of adult males and subadult kin from older litters in care-giving activities. Third, intraspecific variation in parental responsiveness actually means that any species has different variants of social organization represented in a particular set of social units which are formed depending on the conditions of early postnatal development and individual experience of adults. In other words, any species possesses a higher or lower potential for evolutionary transformation of its social structure in both directions, i.e., not only from simple (primitive) to complex form, but also vice versa. For example, if the environmental (or, perhaps, some other) conditions in a population of nonsocial species are changed so that males and females living in breeding pairs jointly rearing their offspring become more competitive than solitary conspecifics, then the initially small proportion of these breeding pairs in the population will be gradually extended due to natural selection; the male contribution to care of the young will be concurrently increased, and the structure of social units will acquire the features of a family-group organization. Thus, the ecological factors (if these are associated with this process) result in alteration of specific social structure not in a direct way, but rather indirectly via proximate (behavioral and physiological) mechanisms. However, relevant preconditions (preadaptations), still vague in their origin, are necessary for switching on these mechanisms.

One such precondition seems to be the demographic processes related to decrease in population density, especially during the reproductive period. Under conditions of low population density, the optimal reproductive strategy for males and females is to be nearby each other because searching for additional mates and shelters is associated with large energy expenses and increased risk of predation. This is a situation that can explain the existence of quasi-monogamous pairs in populations of some promiscuous species during periods of low population density (Plyusnin \& Evsikov, 1983; Viitala, 1994). It should be noted, however, that under such conditions mating partners nevertheless do not occupy one common burrow or nest, because their mutual aggressiveness prevents pair bonding, and a subsequent increase of population density usually reverses the situation making it typical of promiscuous species.

Aggregations (breeding colonies) in rodent populations create additional preconditions for pair bonding that is promoted, first, by a higher frequency of interactions between the individuals occupying overlapped home ranges, and second, by ritualization of their in- 
teractions (Gromov, 2005). Besides, some males exhibit feminized behavior in breeding colonies: they are less aggressive, prone to initiate affiliative behaviors (e.g. allogrooming) as well as inclined to provide parental care (McGuire, 1997; Gromov, 2008, 2009, 2011à). Feminization of male behavior may be brought about, on the one hand, by the action of specific physiological and social factors associated with pre-natal development and post-natal ontogenesis (Clark et al., 1992, 1997, 1998; Clark \& Galef, 2000; De Vries et al., 2002; Simerly, 2002; Morris et al., 2004; Gatewood et al., 2006; Lalmansingh et al., 2008; Gromov, 2011a, b, 2012), and, on the other hand, by the individual experience gained as a result of contact with newborn pups, i.e. by the effect of sensitization (Brown \& Moger, 1983; Dewsbury, 1985; Gromov \& Osadchuk, 2013). No doubt, affiliative interactions jointly with feminization of male behavior promote strengthening of pair bonds which, in turn, contributes to formation of cohesive family groups. Hence, gregarious species have an internal potential for transformation of their social organization into the family-group one, not directly depending on habitat conditions.

If transformation of a social organization results in males and females starting to breed in pairs, its further evolution may not involve external (ecological) factors. Due to sensitization, as well as to other specific hormonal and neural mechanisms underlying pair-bonding and parental behaviors, the male behavior becomes even more feminized. Such males take more active part in care of offspring whose behavior, in turn, due to the additional tactile stimulation received from sires, shifts more profoundly towards its further feminization. As a result, formation of extended family groups becomes possible, and cooperation in these groups reaches the highest level. It extends not only to the maintenance of nest burrows, digging tunnels, foraging, protection and scent marking of the home ranges, and guarding of food stores, but also to direct care of the young in which both adult males and subadult individuals from older litters take an active part (alloparenting).

To summarize, the proposed conceptual model of the evolution of sociality in rodents includes the following main points: (1) sociality should be understood as a continuum that goes from solitary forms through complex, family-group based species; (2) group composition and structure are more important defining attributes of sociality than group size; (3) pair bonding, paternal care, and alloparenting represent necessary preconditions to the evolution of sociality; (4) cooperative behavior (i.e., a social factor) would be the critical force driving sociality; (5) instead, ecological factors would play a secondary role making necessary preconditions or even be unimportant.

This conceptual model may look like a verbal analysis that falls short in bringing all the relevant evidence.
In other words, a comparative analysis quantifying evolutionary transitions between social categories would be very useful to provide empirical support to the main statements. To fulfill such an analysis, it needs to find, in particular, a single (or composite) metric to place species through the sociality continuum. Unfortunately, relevant data concerning correct estimation of different parameters of the spatial-and-ethological population structure (Gromov, 2007, 2008), pair bonding, parental responsiveness, and cooperation are absent for the most of rodent species. Available data are restricted to a very limited number of rodent species and collected with different sampling methods. As a result, these data could not be used for correct inter-species comparative analysis.

The only proper example is a comparative study of eight rodent species carried out with use of uniform sampling methods (Gromov, 2007). This study revealed some possible ways (Figure) of the formation and further evolution of different social units in rodent populations. A system of separate individual home ranges with primarily aggressive interactions between individuals, irrespective of their sex, may be presumed to be the original (primitive) form (like in Gerbillus perpallidus Setzer, 1958, Meriones tamariscinus, Psammomys obe$s u s)$. A decrease in aggressiveness between mates favors pair bonding and, further, formation of family groups (like in Microtus socialis, Lasiopodomys brandtii, Meriones unguiculatus) with delayed offspring dispersal (an arrow along the horizontal projection axis). A decrease in the spatial segregation of adults increases tolerance in their interactions, thereby laying the basis for aggregations (like in M. meridianus) with a dominance hierarchy among males (an arrow along the vertical projection axis). The gerbil Meriones libycus Lichtenstein, 1823 is similar to the vole Microtus socialis in many parameters, and the projections of these species to the horizontal axis (factor 1) are close to each other. However, the space use system is more labile in the former species, which is characterized by a dominance hierarchy among males (factor 2). This makes Meriones libycus closer to M. meridianus. A third way is also possible, namely, strengthening pair bonds in aggregations, which results in the formation of family groups (shown as a dotted arrow).

Another example is comparative studies of pair bonding and parental behaviors in a number of cricetid rodents (Gromov, 2011a, c, d, 2012). These studies show that cooperation associated with parental care extends and intensifies with the transition from a solitary lifestyle to a family-group lifestyle.

These findings enrich our knowledge and provide a better understanding of the evolution of sociality among rodents. Further investigations with utilization of the same sampling methods and comparable data would be very useful for development of the new conceptual model. 


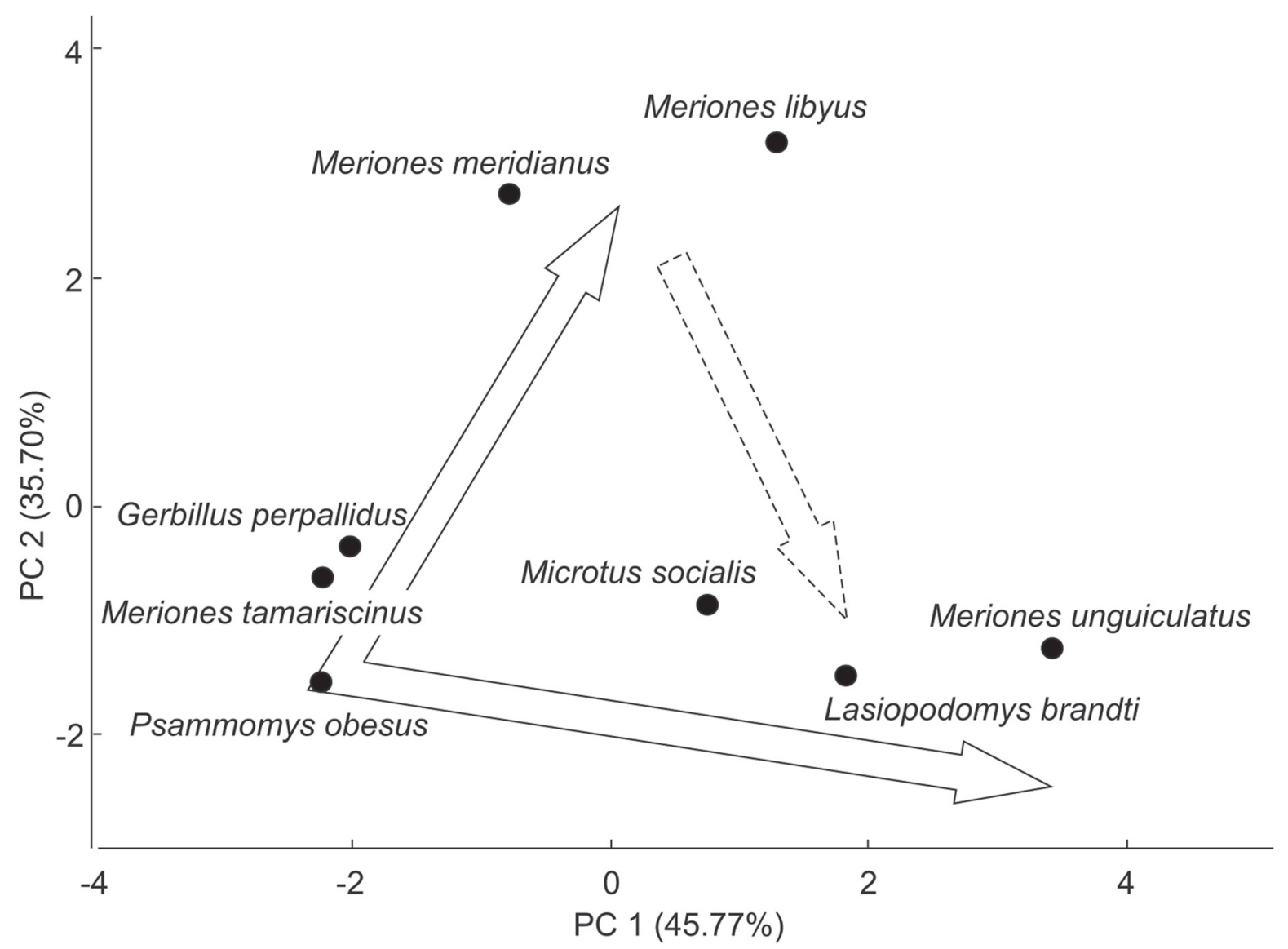

Figure. The result of principal components analysis (PC 1: 45.77\% of variance; PC 2: 35.70\%) based on integrated estimation of the 10 parameters characterizing the spatial-and-ethological population structure of eight rodent species (for detail see Gromov, 2007: 47, Table, Figure). The arrow along the vertical projection axis shows an increase in gregariousness of adults as well as asymmetry in their interactions reflecting the dominance relationships; the arrow along the horizontal projection axis shows a decrease in aggressiveness between mates favoring pair bonding and the formation of family groups with delayed offspring dispersal; the dotted arrow shows enhancement of pair bonding in aggregations.

The evolution of sociality in rodents as an epigenetic phenomenon

Considering the evolution of sociality in rodents as transition from solitary living to family-group lifestyle, it is necessary to realize that this process is not associated with fundamental changes in social behavior. Species living in family groups, with rare exceptions, differ from solitary and gregarious ones in (1) stronger pair bonds, (2) active participation of males in care of offspring, (3) social complexity related, first of all, to cooperation in different activities, and (4) hierarchical relationships due to which, in particular, reproductive functions of offspring are suppressed while the young animals remain as a part of the family group. However, the behavioral repertoire of species belonging to different categories of sociality has pronounced similarity, and inter-specific differences are mainly quantitative, but not qualitative ones. In particular, the strength of pair bonds is defined by the frequency and duration of peaceful interactions including naso-nasal contacts, sniffing, brooding, side-by-side postures, allogrooming, and ritualized behaviors (defensive postures, threatening, compulsory grooming, etc.). All these elements of social behavior are manifested in male-female interactions of solitary and gregarious species as well, but with much smaller frequency and shorter duration, especially during the reproductive period (Gromov, 2008).

The paternal care of the young is also not an exclusive behavioral attribute of species living in family groups. Males of many promiscuous and gregarious species like, for example, Microtus pennsylvanicus, Clethrionomys glareolus, C. rutilus (Pallas, 1779), C. gapperi Vigors, 1830 (Storey \& Snow, 1987; McGuire, 1997; Gromov, 2009; Gromov \& Osadchuk, 2013) exhibit parental responsiveness in captivity, though not at such a high degree as in social species.

The only feature due to which social species (i.e. species living in family groups) qualitatively differ from solitary and gregarious ones is cooperation. But cooperation is manifested not at the individual level, but at 
the level of social groups, and, therefore, this qualitative feature can't be genetically determined because natural selection is the process of selection of genotypes, but not gene pools. Hence, one can conclude that if the evolution of sociality among rodents does not result in profound changes of their behavior, there are no genetically determined and irreversible behavioral differences between the closely related species belonging to different categories of sociality (like, for example, among Marmota, Microtus or Meriones spp.).

A considerable body of evidence indicates that the evolution of sociality in rodents is an epigenetic phenomenon. The foundation of the epigenetic theory of evolution was laid by Schmalhausen (1968) and Shishkin's works (1988). According to the concept of stabilizing selection (Schmalhausen, 1968), it is not changes of genotype that define evolution and its direction, but evolution of the organism that defines changes in its genotype. In the epigenetic theory of evolution (Shishkin, 1988), a lack of close association between genotype and phenotype is postulated, and the main substratum of selection is phenotype. Selection not only fixes useful changes in the phenotype, but also takes part in its creation. This means also that heredity is mainly affected not by a genome, but the epigenetic system, i.e. a set of the factors influencing ontogeny of development. And in the course of evolution, the epigenetic system (for example, hormonal and neural mechanisms involved in the control of behaviors associated with pair bonding and parental care) is inherited as a whole. Natural selection results in stabilization of consecutive ontogeneses, elimination of violations of phenotype (morphoses), and formation of a steady developmental trajectory (creod). According to the epigenetic theory, evolution is transformation of one creod into another one as a result of the impact of specific stress factors.

The epigenetic theory quite logically explains the evolution of different types of the spatial-and-ethological population structure of rodents (Gromov, 2007, 2008, 2011a) and, respectively, different categories of social organization (i.e. gradations of sociality) without a close association with certain ecological factors. Or rather, promoting factors could be various (including social, physiological, etc.), but result in formation of a complex social organization with similar features even in species belonging to different taxa.

Different types of spatial-and-ethological population structure of rodents (Gromov, 2008, 2011a) as well as of social structure (from solitary to family-group ones) could be considered as different variants of the same ontogenetic program resulting from various combinations of the individual genomes and environmental factors. Among the latter, characteristics of the early environment related primarily to parental care (especially, to tactile stimulation of juveniles) may have crucial importance. When the environmental conditions are constant among generations, the selection would favor the most adaptive phenotype leading to gradual growth of its stability in the population and destabilization of the former norm. The epigenetic theory postulates that stability and heritability of norm is a result of regulatory processes within the epigenetic system.

It is well-known that interaction between environment and genome results in alteration of gene expression which, in turn, leads to extension of phenotype variability. Numerous recent contributions deal with the epigenetic regulation resulting from the alteration of gene expression due to DNA methylation, histone acetylation and other factors (Turner et al., 2015).

For instance, in rats with abusing and neglecting mothers expression of the BDNF (brain-derived neurotrophic factor) gene was found to be essentially reduced in the prefrontal cortex where the promoter was also hypermethylated (Roth et al., 2009). The female offspring exposed to early-life maltreatment also presented a similar poor maternal behavior and the same altered BDNF DNA methylation pattern. When the offspring of abusive mothers were cross-fostered by normal mothers, methylation levels of the BDNF promoter did not essentially change. This is obvious evidence that DNA methylation induced by early-life maltreatment can be transmitted across generations.

Another example is experiments with male mice that were exposed to 6 weeks of chronic stress before breeding. This stress regimen perturbed the hypothalamic-pituitary-adrenal axis of the males, and this new phenotype was transmitted to the next generation along with perturbed gene expression and DNA methylation levels (Rodgers et al., 2013).

A low degree of licking and grooming of pups, as well as arched-back nursing, were demonstrated to directly translate into increased DNA methylation of a particular $\mathrm{CpG}$ pair within the glucocorticoid receptor (GR) promoter, with profound and long lasting effects on the recipient stress response (Weaver, 2007). Enhanced methylation led to reduced GR expression, and cross-fostering of pups from high to low caring mothers demonstrated that the effect was due to the maternal behavior (Weaver et al., 2004, 2007).

In the natural population of the prairie vole, Microtus ochrogaster, partner preferences are known to be formed following male-female cohabitation and mating. Under laboratory conditions, this behavior was facilitated in females in absence of mating by inhibiting histone deacetylases. This treatment increased histone acetylation in promoters of the oxytocin receptors (OTR and oxtr) and vasopressin V1a receptors (V1aR, avpr1a) in the nucleus accumbens of the brain producing epigenetic regulation patterns similar to those established by natural mating-induced partner preference. This was interpreted as direct evidence for epigenetic regulation of pair bonding (Turner et al., 2015).

Variation in maternal care was shown to affect the development of individual differences in neuroendocrine responses to stress in rats. As adults, the offspring of mothers that exhibited more licking and grooming of pups showed reduced plasma adrenocorticotropic hor- 
mone and corticosterone responses to stress, increased hippocampal glucocorticoid receptor messenger RNA expression, enhanced glucocorticoid feedback sensitivity, and decreased levels of hypothalamic corticotrophin-releasing hormone messenger RNA. These findings suggest that maternal behavior serves to "program" hypothalamic-pituitary-adrenal responses to stress in the offspring. The revealed effect was not dependent on the time the female spends in a nest with pups or for their nursing (Meaney et al., 1989; Liu et al., 1997; Caldji et al., 1998).

Experiments with cross-fostering have also shown that if pups of the low-caring mothers were placed to the high caring mothers then they became more stressresistant and vice versa. In other words, stress-resistance of the pups was not dependent on a phenotype of biological parents. These findings suggest that individual differences in the expression of genes in brain regions that regulate stress reactivity can be transmitted from one generation to the next through behavior (Francis et al., 1999). This epigenetic effect was found to be associated with DNA methylation (Weaver et al., 2004).

In addition, maternal licking and grooming results in an increased expression of genes controlling receptors of estradiol (ERá) and oxytocin (OTR) which are closely associated with regulation of maternal behavior (Shepard et al., 2009). In general, variations in maternal care can serve as the basis for a nongenomic behavioral transmission of individual differences across generations (Francis et al., 1999). The same effect of paternal licking and grooming can also be expected.

The epigenetic programming of offspring behavior is a result not only of maternal and paternal care (i.e. tactile stimulation due to licking and grooming), but also of sensitization. Stolzenberg et al. (2012) carried out experiments with C57BL/6J female mice and used a histone deacetylase (HDAC) inhibitor, sodium butyrate (SB), which inhibits HDAC activity and increases histone acetylation (Roozendaal et al., 2010). Oral administration of SB increases histone acetylation in the hypothalamus including its medial preoptic area, a specific brain structure involved in the control of parental behavior (Bonthuis et al., 2011). It is well-known that experience with pups can initiate and sustain parental responsiveness (the effect of sensitization, McCarthy, 1990): 4 days of experience (for just $2 \mathrm{~h} /$ day) with pups is required for virgin females to show a high degree of maternal care (licking, grooming, and brooding pups). The treatment with SB reduced by $50 \%$ the amount of maternal experience required to promote maternal responsiveness to pups. These maternal-experience dependent changes in maternal care were associated with an upregulation of expression of 5 genes (Crebbp, Esr2, Oxt, Avp, and Avprla) in the medial preoptic area, and $\mathrm{SB}$ reduced the amount of maternal experience required to promote the expression of 3 of these 5 genes (Crebbp, Esr2, and Oxt) (Stolzenberg et al., 2012). The transmission of maternal responsiveness from mother to daughter has been also found to be associated with the extent to which the regulatory region of the Esr1 gene was methylated (Champagne et al., 2006). These findings help us to uncover the molecular mechanisms through which initial mother-infant interactions induce epigenetic alterations that sustain maternal care during a critical period.

The same effect of sensitization (i.e. experience with pups) on paternal responsiveness can also be expected, and this suggestion is substantiated by the results of the experiments with males of some rodent species (Brown \& Moger, 1983; Dewsbury, 1985; McCarthy, 1990; Walsh et al., 1996; Gromov \& Osadchuk, 2013).

Thus, experimental studies convincingly prove that there is epigenetic restructuring of neural mechanisms involved into the control of behaviors associated with pair bonding and parental care which in turn promote transition from solitary living to family-group life strategy. According to the epigenetic theory, the most important stress-factors affecting neuroendocrine control of social behavior and providing epigenetic «programming» of individuals in consistence with a family-group lifestyle are the higher level of tactile stimulation of juveniles and experience with pups causing the effect of sensitization. These two stress-factors are not associated with ecological conditions like predation or resource distribution, so one can conclude that profound transformation of social structure in rodent populations can occur irrespective of external environment if one doesn't include the social conditions in this concept.

The occurrence of individuals with endophenotype that can be conditionally characterized as 'the careful partner and better parent' (Phelps \& Ophir, 2009; Phelps, 2010) automatically promotes cooperation between mates associated with joint burrowing and digging tunnels, protecting and scent marking of the common home range, and subsequent care of the young. If cooperation creates some advantages for long-lasting pair bonds versus solitary-living strategy, natural selection will favors gradual increase of the proportion of individuals with the aforementioned endophenotype in the population, and the family-group organization will evolve and prevail among social units of the species. In terms of the socioecological concept, such a species should be considered as not solitary living, but a social one.

\section{Conclusion}

In rodent populations, there are two main types of complex social units - aggregations (breeding colonies) and family groups, and their basic features of the social organization are quite different. Impact of ecological factors, including predation and food resources, on the evolution of sociality in rodents, i.e. transition from solitary living to a family-group lifestyle, is still unclear. It seems that a set of ecological conditions resulting in evolution towards a family-group lifestyle is unique for any rodent species, and there are no 
universal rules explaining the effect of external factors on species-specific social organization.

The epigenetic theory provides quite a convincing explanation of formation of various social units in rodent populations, related to different categories of sociality, without close association with certain ecological factors. Or rather, selective factors may be various (including social, physiological, developmental, etc.), but result in formation of social organization with similar features in species belonging to different taxa. Environmental factors may create necessary preconditions, but these ones are not sufficient for complete transformation of social structure into a family-group one. The main driving forces are proximate mechanisms promoting pair bonding and stimulation of parental care in males, as well as cooperation. In rodents, cooperation extends and intensifies when the size of family groups increases as a result of delayed offspring dispersal. Due to cooperation, family groups become more competitive than solitary conspecifics.

According to the proposed conceptual model, any rodent species possesses a higher or lower potential for evolutionary transformation of its social structure and organization, and this transformation may be possible in both directions, i.e., not only from simple (primitive) to complex forms, but also vice versa.

ACKNOWLEDGEMENTS. The study was supported by Russian Foundation for Basic Research (grants 02-04-48419, 07-04-00142, 11-04-00162, 15-04-00819). I am also grateful to E.N. Panov and M.A. Potapov for their valuable comments.

\section{References}

Ågren G., Zhou Q. \& Zhong W. 1989a. Ecology and social behaviour of Mongolian gerbils, Meriones unguiculatus, at Xilinhot, Inner Mongolia, China // Animal Behaviour. Vol.37. P.11-27.

Ågren G., Zhou Q. \& Zhong W. 1989b. Territoriality, cooperation and resource priority in the Mongolian gerbil, Meriones unguiculatus // Animal Behaviour. Vol.37. P.28-32.

Alexander R.D. 1974. The evolution of social behavior // Annual Reviews in Ecology and Systematics. Vol.5. P.325-383.

Armitage K.B. 1962. Social behavior of the yellow-bellied marmot (Marmota flaviventris) // Animal Behaviour. Vol.10. P.319-331.

Armitage K.B. 1981. Sociality as a life-history tactic of ground squirrels // Oecologia (Berlin). Vol.48. P.36-49.

Armitage K.B. 1999. Evolution of sociality in marmots // Journal of Mammalogy. Vol.80. P.1-10.

Armitage K.B. 2007. Evolution of sociality in marmots: It begins with hibernation // Wolff J.O. \& Sherman P.W. (eds.). Rodent societies: An ecological and evolutionary perspective. Chicago: University of Chicago Press. P.356367.

Arnold W. 1990a. The evolution of marmot sociality: I. Why disperse late? // Behavioral Ecology and Sociobiology. Vol.27. P.229-237.
Arnold W. 1990b. The evolution of marmot sociality: II. Costs and benefits of joint hibernation // Behavioral Ecology and Sociobiology. Vol.27. P.239-246.

Arnold W. 1993. Energetics of social hibernation // Carey C., Florant G.L., Wunder B.A. \& Horwitz B.B. (eds.). Life in the cold: Ecological, physiological and molecular mechanisms. Colorado: Westview Press. P.65-80.

Barash D.P. 1973. The social biology of the Olympic marmot (Marmota olympus) // Animal Behavior Monographs. Vol.6. P.171-245.

Barash D.P. 1974. The evolution of marmot societies: a general theory // Science. Vol.185. P.415-420.

Barash D.P. 1976. Social behaviour and individual differences in free-living alpine marmots (Marmota marmota) // Animal Behaviour. Vol.24. P.27-35.

Bennett N.C. \& Faulkes C.G. 2000. African mole-rats: ecology and eusociality. Cambridge: Cambridge University Press. 189 p.

Blumstein D.T. 1996. How much does social group size influence golden marmot vigilance? // Behaviour. Vol.133. P.1133-1151.

Blumstein D.T. \& Armitage K.B. 1997. Does sociality drive the evolution of communicative complexity? A comparative test with ground-dwelling sciurid alarm calls // American Naturalist. Vol.150. P.179-200.

Blumstein D.T. \& Armitage K.B. 1998. Life history consequences of social complexity: a comparative study of ground-dwelling sciurids // Behavioral Ecology. Vol.9. P.8-19.

Blumstein D.T., Steinmetz J. \& Armitage K.B. 1997. Alarm calling on yellow-bellied marmots. II. The importance of direct fitness // Animal. Behaviour. Vol.53. P.173-184.

Bonthuis P.J., Patteson J.K. \& Rissman E.F. 2011. Acquisition of sexual receptivity: roles of chromatin acetylation, estrogen receptor-alpha, and ovarian hormones // Endocrinology. Vol.152. P.3172-3181.

Brown R.E. \& Moger W.H. 1983. Hormonal correlates of parental behavior in male rats // Hormones and Behavior. Vol.17. P.356-365.

Bujalska G. \& Saitoh T. 2000. Territoriality and its consequences // Polish Journal of Ecology. Vol.48. Suppl. P.37-49.

Burda H. 1990. Constraints of pregnancy and evolution of sociality in mole-rats with special reference to reproductive and social patterns in Cryptomys hottentotus (Bathiergidae, Rodentia) // Zeitschrift für Zoologie und Systematische Evolutionsforschung. Bd.28. S.26-39.

Burda H., Honeycutt R.H., Begall S., Locker-Grütjen O. \& Scharff A. 2000. Are naked and common mole-rats eusocial, and if so, why? // Behavioral Ecology and Sociobiology. Vol.47. P.293-303.

Busher P. 2007. Social organization and monogamy in the beaver // Wolff J.O. \& Sherman P.W. (eds.). Rodent societies: An ecological and evolutionary perspective. Chicago: University of Chicago Press. P.280-290.

Caldji C., Tannenbaum B., Sharma S., Francis D., Plotsky P.M. \& Meaney M.J. 1998. Maternal care during infancy regulates the development of neural systems mediating the expression of fearfulness in the rat // Proceedings of National Academy of Sciences. Vol.95. P.5335-5340. 
Carey H.V. \& Moore P. 1986. Foraging and predation risk in yellow-bellied marmots // American Midland Naturalist. Vol.116. P,267-275.

Carr G.M. \& Macdonald D.W. 1986. The sociality of solitary foragers: A model based on resource dispersion // Animal Behaviour. Vol.34. P.1540-1549.

Carter C.S. \& Getz L.L. 1993. Monogamy and prairie vole / / Scientific American. Vol.268. P.100-106.

Carter C.S. \& Roberts R.L. 1997. The psychobiology of cooperative breeding in rodents // Solomon N.G. \& French J. (eds.). Cooperative breeding in mammals. Cambridge: Cambridge University Press. P.231-266.

Carter C.S., De Vries A.C. \& Getz L.L. 1995. Physiological substrates of mammalian monogamy: the prairie vole model // Neuroscience and Biobehavior Reviews. Vol.19. P.303-314

Champagne F.A., Weaver I.C., Diorio J., Dymov S., Szyf M. \& Meaney M.J. 2006. Maternal care associated with methylation of the estrogen receptor-alphalb promoter and estrogen receptor-alpha expression in the medial preoptic area of female offspring // Endocrinology. Vol.147. P.2909-2915.

Clark M. \& Galef B.G., Jr. 2000. Why some male Mongolian gerbils may help at the nest: testosterone, asexuality and alloparenting // Animal Behaviour. Vol.59. P.801-806.

Clark M.M., vom Saal F.S. \& Galef B.G. 1992. Intrauterine positions and testosterone levels of adult male gerbils are correlated // Physiology and Behavior. Vol.51. P.957960.

Clark M., Desousa D., Vonk J. \& Galef B.G. 1997. Parenting and potency: alternative routes to reproductive success in male Mongolian gerbils // Animal Behaviour. Vol.54. P.635-642.

Clark M.M., Vonk J. \& Galef B.G., Jr. 1998. Intrauterine position, parenting, and nest site-attachment in male Mongolian gerbils // Developmental Psychobiology. Vol.32. P.177-181.

Clutton-Brock T.H. 1974. Primate social organization and ecology // Nature. Vol.250. P.539-542.

Corbet N.U. \& van Aarde R.J. 1996. Social organization and space use in the Cape porcupine in a southern African savanna // African Journal of Ecology. Vol.34. P.1-14.

Crook J.H. 1970a. The socio-ecology of primates // Crook J.H. (ed.). Social behaviour in birds and mammals. London: Academic Press. P.103-156.

Crook J.H. 1970b. Social organization and the environment: aspects of contemporary social ethology // Animal Behaviour. Vol.18. P.197-209.

Daly M. \& Daly S. 1974. Spatial distribution of a leaf-eating Saharan gerbil (Psammomys obesus) in relation to its food // Mammalia. Vol.38. P.591-603.

Danielson B.J. \& Gaines M.S. 1987. Spatial patterns in two synoptic species of microtines: Microtus ochrogaster and Synaptomys cooperi // Journal of Mammalogy. Vol.68. P.313-322.

De Vries G.J., Rissman E.F., Simerly R.B., Yang L.Y., Scordalakes E.M. \& Auger C.J. 2002. A model system for study of sex chromosome effects on sexually dimorphic neural and behavioral traits // Journal of Neuroscience. Vol.22. P.9005-9014.
Dewsbury D.A. 1985. Paternal behavior in rodents // American Zoologist. Vol.25. P.841-852.

Ebensperger L.A. \& Cofré H. 2001. On the evolution of group-living in the New World cursorial hystricognath rodents // Behavioral Ecology. Vol.12. P.227-236.

Ebensperger L.A., Wallem P.K. 2002. Grouping increases the ability of the social rodent, Octodon degus, to detect predators when using exposed mictohabitats // Oikos. Vol.98. P.491-497.

Ebensperger L.A., Veloso C. \& Wallem P.K. 2002. Do female degus communally nest and nurse their pups? // Journal of Ethology. Vol.20. P.143-146.

Ebensperger L.A., Hurtado M.J. \& Ramos-Jiliberto R. 2006. Vigilance and collective detection of predators in degus (Octodon degus) // Ethology. Vol.112. P.879-887.

Ebensperger L.A., Sobrero R., Quirici V., Castro R., Tolhuysen L.O., Vargas F., Burger J.R., Quispe R., Villavicencio C.P., Vasquez R.A. \& Hayes L.D. 2012. Ecological drivers of group living in two populations of the communally rearing rodent, Octodon degus // Behavioral Ecology and Sociobiology. Vol.66. P.261-275.

Eisenberg J.F., Muckenhirn N.A. \& Rudran R. 1972. The relation between ecology and social structure in primates // Science. Vol.176. P.863-874.

Elwood R.W. 1975. Paternal and maternal behaviour in the Mongolian gerbil // Animal Behaviour. Vol.23. P.766772.

Elwood R.W. 1979. Maternal and paternal behaviour of the Mongolian gerbil: a correlation study // Behavioral and Neural Biology. Vol.25. P.555-562.

Elwood R.W. \& Broom D.M. 1978. The influence of litter size and parental behaviour on the development of Mongolian gerbil pups // Animal Behaviour. Vol.26. P.438454.

Faulkes C.G., Bennett N.C., Bruford M.W., O'Brien H.P., Aguilar G.H. \& Jarvis J.U.M. 1997. Ecological constraints drive social evolution in African mole-rats // Proceedings of Royal Society, London, Series B. Vol.264. P.1619-1627.

Fleming A.S. \& Luebke C. 1981. Timidity prevents the nulliparous female from being a good mother // Physiology and Behavior. Vol.27. P.863-868.

Fleming A.S. \& Sarker J. 1990. Experience-hormone interactions and maternal behavior in rats // Physiology and Behavior. Vol.47. P.1165-1173.

Fleming A.S., O’Day D.H. \& Kraemer G.W. 1999. Neurobiology of mother-infant interactions: experience and central nervous system plasticity across development and generations // Neuroscience and Biobehavior Reviews. Vol.23. P.673-685.

Fleming A.S., Kraemer G.W., Gonzalez A., Lovic V., Rees S. \& Melo A. 2002. Mothering begets mothering: the transmission of behavior and it neurobiology across generations // Pharmacology and Biochemical Behavior. Vol.73. P.61-75.

Foster J. \& Gaines M.S. 1991. The effects of successional habitat mosaic on a small mammal community // Ecology. Vol.72. P.1358-1373.

Francis D., Diorio J., Liu D. \& Meany M.J. 1999. Nongenomic transmission across generations of maternal be- 
havior and stress responses in the rat // Science. Vol.286. P.1155-1158.

French J.A. 1994. Alloparents in the Mongolian gerbil: impact on long-term reproductive performance of breeders and opportunities for independent reproduction // Behavioral Ecology. Vol.5. P.273-279.

Gatewood J.D., Wills A., Shetty S., Xu J., Arnold A.P. \& Burgoyne P.S. 2006. Sex chromosome complement and gonadal sex influence on aggressive and parental behaviors in mice // Journal of Neuroscience. Vol.26. P.23352342.

Gerling S. \& Yahr P. 1979. Effect of the male parent on pup survival in Mongolian gerbils // Animal Behaviour. Vol.27. P.310-311.

Getz L.L. 1985. Habitats // Tamarin R.H. (ed.). Biology of New World Microtus. Stillwater, Oklahoma: The American Society of Mammalogists. P.286-309.

Getz L.L., Carter C.S. \& Gavish L. 1981. The mating system of the prairie vole, Microtus ochrogaster: field and laboratory evidence for pair bonding // Behavioral Ecology and Sociobiology. Vol.8. P.189-194.

Getz L.L., McGuire B., Pizzuto T., Hofmann J.E. \& Frase B. 1993. Social organization of the prairie vole (Microtus ochrogaster) // Journal of Mammalogy. Vol.74. P.4458.

Gonzalez A., Lovic V., Ward G.R., Wainwright P.E. \& Fleming A.S. 2001. Intergenerational effects of complete maternal deprivation and replacement stimulation on maternal behavior and emotionality in female rats // Developmental Psychobiology. Vol.38. P.11-32.

Gromov V.S. 2001. Day-time activity and social interactions in a colony of the fat sand rats, Psammomys obesus, at the Negev Highlands, Israel // Mammalia. Vol.65. P.1328.

Gromov V.S. 2005. [Ritualized agonistic behavior in rodents] // Uspekhi Sovremennoi Biologii. Vol.125. P.522533 [in Russian, with English summary].

Gromov V.S. 2007. Spatial ethological structure and evolution of sociality in rodents // Doklady Biological Sciences. Vol.412. P.46-48.

Gromov V.S. 2008. [The spatial-and-ethological population structure in rodents]. Moscow: KMK Scientific Press. 581 p. [in Russian].

Gromov V.S. 2009. Interactions of partners in family pairs, care of the offspring, and the role of tactile stimulation in formation of parental behavior of the Mongolian gerbil (Meriones unguiculatus) under laboratory conditions // Biology Bulletin. Vol.36. P.479-488.

Gromov V.S. 2011a. Parental care, tactile stimulation and sociality evolution in rodents: Behavioural, physiological and developmental aspects. Saarbrücken: Lambert Acad. Publ. 104 p.

Gromov V.S. 2011b. Rodents and space: What behavior do we study under semi-natural and laboratory conditions? // Triunvery A. \& Scalise D. (eds.). Rodents: Habitat pathology and environmental impact. New York: Nova Science Publishers. P.43-60.

Gromov V.S. 2011c. Pair-bonding and parental care in cricetid rodents: a comparative study // Acta Theriologica. Vol.56. P.23-33.
Gromov V.S. 2011d. Biparental care, tactile stimulation, and evolution of sociality in rodents // Journal of Evolutionary Biology Research. Vol.3. P.33-43.

Gromov V.S. 2012. The early experience of tactile stimulation and its behavioral consequences related to socialization in mammals // Andersen E.L. \& Thomas S. (eds.). Socialization: theories, processes and impact. New York: Nova Science Publishers. P.1-28.

Gromov V.S. 2013. Care of young and the effect of the presence of a male on parental behavior in the common vole (Microtus arvalis) in captivity // Contemporary Problems of Ecology. Vol.6. P.330-335.

Gromov V.S., Krasnov B.R. \& Shenbrot G.I. 2000. Space use in Wagner's gerbil, Gerbillus dasyurus (Wagner, 1842), in the Negev Highlands, Israel // Acta Theriologica. Vol.45. P.175-182.

Gromov V.S. \& Osadchuk L.V. 2013. Parental care and testosterone in males of the bank vole (Myodes glareo$l u s)$ : Sensitization and androgenic stimulation of paternal behavior // Biology Bulletin. Vol.40. P.114-118.

Gubernick D.J. \& Teferi T. 2000. Adaptive significance of male parental care in monogamous mammal // Proceedings of. Royal Society, London, Series B. Vol.267. P.147150.

Gubernick D.J., Wright S.L. \& Brown R.E. 1993. The significance of father's presence for offspring survival in the monogamous California mouse, Peromyscus californicus // Animal Behaviour. Vol.46. P.539-546.

Hare J.F. \& Murie J.O. 2007. Ecology, kinship, and ground squirrel sociality: Insights from comparative analyses // Wolff J.O. \& Sherman P.W. (eds.). Rodent societies: An ecological and evolutionary perspective. Chicago: University of Chicago Press. P.345-355.

Hayes L.D., Chesh A.S., Castro R.A., Tolhuysen L.O., Burger J.R., Bhattacharjee J. \& Ebensperger L.A. 2009. Fitness consequences of group living in the degu Octodon degus, a plural breeder rodent with communal care // Animal Behavior. Vol.78. P.131-139.

Heaney L.R. \& Thorington R.W., Jr. 1978. Ecology of Neotropical red-tailed squirrels, Sciurus granatensis, in the Panama Canal Zone // Journal of Mammalogy. Vol.59. P.846-851.

Hladik C.M. 1975. Ecology, diet and social patterning in Old and New World primates // Tuttle R.H. (ed.). Socioecology and psychology of primates. Den Haag: Mouton. P.3-35.

Holmes W.G. \& Mateo J.M. 2007. Fin recognition in rodents: Issues and evidence // Wolff J.O. \& Sherman P.W. (eds.). Rodent societies: An ecological and evolutionary perspective. Chicago: University of Chicago Press. P.216230.

Hoogland J.L. 1979. The effect of the colony size on individual alertness of prairie dogs (Sciuridae: Cynomys spp.) // Animal Behaviour. Vol.27. P.394-407.

Hoogland J.L. 1981. The evolution of coloniality in whitetailed and black-tailed prairie dogs (Sciuridae: Cynomys leucurus and C. ludovicianus) // Ecology. Vol.62. P.252272.

Janson C.H. 1992. Evolutionary ecology of primate social structure // Smith E.A. \& Winterhalder B. (eds.). Evolu- 
tionary ecology and human behavior. New York: Walter de Gruyter. P.95-130

Jarman P.J. 1974. The social organisation of antelope in relation to their ecology // Behaviour. Vol.48. P.215-267.

Jarvis J.U.M. 1981. Eusociality in a mammal: cooperative breeding in naked mole-rat colonies // Science. Vol.212. P.571-573.

Jarvis J.U.M., O’Riain M.J., Bennett N.C. \& Sherman P.W. 1994. Mammalian eusociality: a family affair // Trends in Ecology and Evolution. Vol.9. P.47-51.

Jêdrzejewski W., Jêdrzejewska B. \& McNeish E. 1992. Hunting success of the weasel Mustela nivalis and escape tactics of forest rodents in $\mathrm{Bia}^{3}$ owie ${ }_{\text {i }}$ National Park // Acta Theriologica. Vol.37. P.319-328.

Kasatkin M.V. 2002. [The biology, ecology, and the population structure of the social vole (Microtus socialis Pall.)] // Sbornik nauchnykh trudov gosudarstvennogo biologicheskogo muzeya K.A. Timiryaseva [Proceedings of Timiryasev's State Biological Museum]. Moscow. P.103142 [in Russian].

Kokko H., Johnstone R.A. \& Cluttom-Brock T.H. 2001. The evolution of cooperative breeding through group augmentation // Proceedings of Royal Society, London, Series B. Vol.268. P.187-196.

Krause J. \& Ruxton G.D. 2002. Living in groups. Oxford: Oxford University Press. 286 p.

Lacey E.A. 2004. Sociality reduces individual direct fitness in a colonially breeding rodent, the colonial tuco-tuco (Ctenomys sociabilis) // Behavioral Ecology and Sociobiology. Vol.56. P.449-457.

Lacey E.A. \& Ebensperger L.A. 2007. Social structure in octodontid and ctenomyid rodents // Wolff J.O. \& Sherman P.W. (eds.). Rodent societies: An ecological and evolutionary perspective. Chicago: University of Chicago Press. P.403-415.

Lacey E.A. \& Sherman P.W. 2007. The ecology of sociality in rodents // Wolff J.O. \& Sherman P.W. (eds.). Rodent societies: An ecological and evolutionary perspective. Chicago: University of Chicago Press. P.243-254.

Lacey E.A., Braude S.H. \& Wieczrek J.R. 1997. Burrow sharing by colonial tuco-tucos (Ctenomys sociabilis) // Journal of Mammalogy. Vol.78. P.556-562.

Lalmansingh A.A., Tejada L.D., Weaver J.L. \& Rissman E.F. 2008. Sex chromosome complement affects social interactions in mice // Hormones and Behavior. Vol.54 P.565-570.

Liu D., Diorio J., Tannenbaum B., Caldji C., Francis D., Freedman A. \& Shanna S. 1997. Maternal care, hippocampal glucocorticoid receptors, and hypothalamic-pituitary-adrenal responses to stress // Science. Vol.277. P.1659-1662.

Macdonald D.W. 1981. Dwindling resources and the social behaviour of Capybaras, (Hydrochoerus hydrochaeris) (Mammalia) // Journal of Zoology. Vol.194. P.371-391.

Macdonald D.W. \& Carr G.M. 1989. Food security and the rewards of tolerance // British Ecological Society Special Publication. Vol.8. P.75-99.

Madison D.M., FitzGerald R.W. \& McShea W.J. 1984. Dynamics of social nesting in overwintering meadow voles (Microtus pennsylvanicus): possible consequences for population cycling // Behavioral Ecology and Sociobiology. Vol.15. P.9-17.

Marinelli L. \& Messier F. 1995. Parental care strategies among musk-rats in a female-biased population // Canadian Journal of Zoology. Vol.73. P.1503-1510.

Mashkin V.I. 1983. [Intraspecific relationships among marmots Marmota menzbieri] // Fauna i ekologia gryzunov. Vol.15. P. 204-224 [in Russian].

McCarthy M.M. 1990. Short-term early exposure to pups alters infanticide in adulthood in male but not in female wild house mice (Mus domesticus) // Journal of Comparative Psychology. Vol.104. P.195-197.

McGuire B. 1988. Effects of cross-fostering on parental behaviour of meadow voles (Microtus pennsylvanicus) // Journal of Mammalogy. Vol.69. P.332-341.

McGuire B. 1997. Influence of father and pregnancy on maternal care in red-backed voles // Journal of Mammalogy. Vol.78. P.839-849.

McGuire B. \& Novak M. 1984. A comparison of maternal behaviour in the meadow vole (Mictotus pennsylvanicus), prairie vole (M. ochrogaster) and pine vole ( $M$. pinetorum) // Animal Behaviour. Vol.32. P.1132-1141.

McGuire B., Getz L.L. \& Oli M.K. 2002. Fitness consequences of sociality in prairie voles, Microtus ochrogaster: influence of group size and composition // Animal Behaviour. Vol.64. P.645-654.

Meaney M.J., Aitken D.H., Viau V., Sharma S. \& Sarrieau A. 1989. Neonatal handling alters adrenocortical negative feedback sensitivity and hippocampal type II glucocorticoid receptor binding in the rat // Neuroendocrinology. Vol.50. P.597-604.

Meaney M.J. \& Champagne F.A. 2000. Latency to maternal behaviour in high and low licking and grooming mother/ offspring // Society of Neuroscience. Abstr. 26. New Orleans, Louisiana. P.2035.

Molteno A.J. \& Bennett N.C. 2002. Rainfall, dispersal, and reproductive inhibition in eusocial Damaraland molerats (Cryptomys damarensis) // Journal of Zoology. Vol.256. P.445-448.

Morris J.A., Jordan C.L. \& Breedlove S.M. 2004. Sexual differentiation of the vertebrate nervous system // Nature Neuroscience. Vol.7. P.1034-1039.

Nel J.A.J. 1975. Aspects of the social ethology of some Kalahari rodents // Zeitschrift für Tierpsychologie. Bd.37. S.322-331.

Nunes S. 2007. Dispersal and philopatry // Wolff J.O. \& Sherman P.W. (eds.). Rodent societies: An ecological and evolutionary perspective. Chicago: University of Chicago Press. P.150-162.

Ostfeld R.S. 1990. The ecology of territoriality in small mammals // Trends in Ecology and Evolution. Vol.5. P. 411-415.

Patenaude F. 1983. Care of young in a family of wild beavers, Castor canadensis // Acta Zoologica Fennica. Vol.174. P.121-122.

Phelps S.M. 2010. From endophenotypes to evolution: social attachment, sexual fidelity and the avprla locus // Current Opinion in Neurobiology. Vol.20. P.795-802.

Phelps S.M. \& Ophir A.G. 2009. Monogamous brains and alternative tactics: neuronal V1aR, space use and sexual 
infidelity among male prairie voles // Dukas R. \& Ratcliffe J.M. (eds.). Cognitive Ecology II. Chicago: University of Chicago Press. P.156-176.

Plyusnin Yu.M. \& Evsikov V.I. 1983. [Seasonal changes in social organization of reproductive groups of aquatic vole] // Orlov V.N. (ed.). Populyatsionnaya izmenchivost' i problemy okhrany genofonda mlekopitayushchikh [Population variability and protection of pool of mammals]. Moskwa: AN SSSR. P.155-157 [in Russian].

Pollard K.A. \& Blumstein D.T. 2008. Time allocation and the evolution of group size // Animal Behaviour. Vol.76. P.1683-1699.

Priestnall R. \& Young S. 1978. An observational study of caretaking behavior of male and female mice housed together // Developmental Psychobiology. Vol.11. P.23-30.

Pulliam H.R. 1973. On the advantages of flocking // Journal of Theoretical Biology. V.38. P.419-422.

Roberts R.L., Cushing B.S. \& Carter C.S. 1998a. Intraspecific variation in the induction of female sexual receptivity in prairie voles // Physiology and Behavior. Vol.64. P.209-212.

Roberts R.L., Williams J.R., Wang A.K. \& Carter C.S. 1998b. Cooperative breeding and monogamy in prairie voles: influence of the sire and geographic variation // Animal Behaviour. Vol.55. P.1131-1140.

Roberts R.L., Miller A.K., Taymans S.E. \& Carter C.S $1998 \mathrm{c}$. Role of social and endocrine factors in alloparental behaviour of prairie voles (Microtus ochrogaster) // Canadian Journal of Zoology. Vol.76. P.1862-1869.

Rodgers A.B., Morgan C.P., Bronson S.L., Revello S. \& Bale T.L. 2013. Paternal stress exposure alters sperm microRNA content and reprograms offspring HPA stress axis regulation // Journal of Neuroscience. Vol.33. P.9003-9012.

Rogovin K.A., Moshkin M.P. \& Randall J.A. 2003. [Availability of resources, demography and physiological stress in population of great gerbil (Rhombomys opimus Licht.) in conditions of peak and decline density] // Zoologicheskii Zhurnal. Vol.82. P.497-507 [in Russian with English summary].

Roozendaal B., Hernandez A., Cabrera S.M., Hagewoud R., Malvaez M., Stefanko D.P., Haettig J. \& Wood M.A. 2010. Membrane-associated glucocorticoid activity is necessary for modulation of long-term memory via chromatin modification // Journal of Neuroscience. Vol.30. P.5037-5046.

Roth T.L., Lubin F.D., Funk A.J. \& Sweatt J.D. 2009 Lasting epigenetic influence of early-life adversity on the BDNF gene // Biology and Psychiatry. Vol.65. P.760 769.

Schaik C.P., van \& van Hooff J.A.R.A.M. 1983. On the ultimate causes of primate social systems // Behaviour. Vol.85. P.91-117.

Schmalhausen I.I. 1968. [The factors of evolution: The concept of stabilizing selection]. Moscow: Izdatelstvo Nauka. 268 p. [in Russian].

Shepard K.N., Michopoulos V., Toufexis D.J. \& Wilson M.E. 2009. Genetic, epigenetic and environmental impact on sex differences in social behavior // Physiology and Behavior. Vol.97. P.157-170.
Sherman P.W. 1997. Nepotism and the evolution of alarm calls // Science. Vol.197. P.1246-1253.

Shishkin M.A. 1988. [Evolution as an epigenetic process] // [The modern paleontology]. Vol.2. Part 7. [The general regularities of the organic world]. Moscow: Nedra. P.142168 [in Russian].

Shilton C.M. \& Brooks R.J. 1989. Paternal care in captive collared lemmings (Dicrostonyx richardsoni) and its effect on development of the offspring // Canadian Journal of Zoology. Vol.67. P.2740-2744.

Simerly R.B. 2002. Wired for reproduction: organization and development of sexually dimorphic circuits in the mammalian forebrain // Annual Review of Neuroscience. Vol.25. P.507-536.

Slobodchifoff C.N. 1984. Resources and the evolution of social behavior // Price P.W., Slobodchikoff C.N. \& Gaud W.S. (eds.). A new ecology: Novel approaches to interactive systems. New York: John Wiley and Sons. P.227-251.

Smorkatcheva A.V. 2003. Parental care in the captive mandarin vole, Lasiopodomys mandarinus // Canadian Journal of Zoology. Vol.81. P.1339-1345.

Solomon N.G. 1993. Comparison of parental behaviour in male and female prairie voles (Microtus ochrogacter) // Canadian Journal of Zoology. Vol.71. P.434-437.

Solomon N.G. 2003. A reexamination of factors influencing philopatry in rodents // Journal of Mammalogy. Vol.84. P.1182-1197.

Solomon N.G. \& Keane B. 2007. Reproductive strategies in female rodents // Wolff J.O. \& Sherman P.W. (eds.). Rodent societies: An ecological and evolutionary perspective. Chicago: University of Chicago Press. P.42-56.

Stolzenberg D.S., Stevens J.S. \& Rissman E.F. 2012. Experience-facilitated improvements in pup retrieval; evidence for an epigenetic effect // Hormones and Behavior. Vol.62. P.128-135.

Storey A.E. \& Snow D.T. 1987. Male identity and enclosure size effect paternal attendance of meadow voles, Microtus pennsylvanicus // Animal Behaviour. Vol.35. P.411419.

Suntsov V.V. 1981. [The territorial structure and intraspecific relationships in populations of Marmota sibirica in the Tuva region] // Zoologicheskii Zhurnal. Vol.60. P.13941405 [in Russian with English summary].

Taber A.B. \& Macdonald D.W. 1992. Communal breeding in the mara, Dolichotis patagonum (Rodentia: Caviomorpha) // Journal of Zoology. Vol.227. P.439-452.

Terborgh J. \& Janson C.H. 1986. The socioecology of primate groups // Annual Reviews in Ecology and Systematics. Vol.17. P.111-135.

Travis S.E. \& Slobodchikoff C.N. 1993. Effects of food resource distribution on the social system of Gunnison's prairie dog (Cynomys gunnisoni) // Canadian Journal of Zoology. Vol.71. P.1186-1192.

Turner J.D., Kirschner S.A., Molitor A.M., Evdokimov K. \& Muller C.P. 2015. Epigenetics // Wright J.D. (ed.). International Encyclopedia of Social and Behavioral Sciences, 2nd ed. Amsterdam, Boston, Heidelberg, London, New York, Oxford, Paris, San Diego, San Francisco, Singapore, Sydney, Tokyo: Elsevier. P.839-847. 
Uvnäs-Moberg K. 1998. Oxytocin may mediate the benefits of positive social interaction and emotions // Psychoneuroendocrinology. Vol.23. P.819-835.

Vestal B.M. \& McCarley H. 1984. Spatial and social relations of kin in thirteen-lined and other ground squirrels // Murie J.O. \& Michener G.R. (eds.). The biology of ground-dwelling squirrels. Lincoln: University of $\mathrm{Ne}-$ braska Press. P.403-423.

Viitala J. 1994. Monogamy in free living Microtus oeconomus // Annales Zoologici Fennici. Vol.31. P.343-345.

Walsh C.J., Fleming A.S., Lee A. \& Magnusson J.E. 1996. The effects of olfactory and somatosensory desensitization on Fos-like immunoreactivity in the brains of pupexposed postpartum rats // Behavioral Neuroscience. Vol.110. P.134-153.

Wang Z.X. \& Insel T.R. 1996. Parental behavior in voles // Advances in Study of Behavior. Vol.25. P.361-384.

Wang Z.X. \& Novak M.A. 1992. Influence of the social environment on parental behavior and pup development of meadow voles (Microtus pennsylvanicus) and prairie voles (Microtus ochrogaster) // Journal of Comparative Psychology. Vol.106. P.163-171.

Wang Z.X. \& Novak M.A. 1994. Alloparental care and the influence of father presence on juvenile prairie voles, Microtus ochrogaster // Animal Behaviour. Vol.47. P.282-288.

Waterman J. 2007. Male mating strategies in rodents // Wolff J.O. \& Sherman P.W. (eds.). Rodent societies: An eco- logical and evolutionary perspective. Chicago: University of Chicago Press. P.27-41.

Weaver I.C. 2007. Epigenetic programming by maternal behavior and pharmacological intervention. Nature versus nurture: let's call the whole thing off // Epigenetics. Vol.2. P.22-28.

Weaver I.C., Cervoni F., Champagne A., D'Alessio S., Sharma J., Seckl S., Dymov M., Szyf M. \& Meany M. 2004. Epigenetic programming by maternal behavior // Nature Neuroscience. Vol.7. P.847-854.

Weaver I.C., D'Alessio A.C., Brown S.E., Hellstrom I.C., Dymov S., Sharma S., Szyf M. \& Meaney M.J. 2007. The transcription factor nerve growth factor-inducible protein a mediates epigenetic programming: altering epigenetic marks by immediate-early genes // Journal of Neuroscience. Vol.27. P.1756-1768.

Wuensch K.L. 1985. Effects of early paternal presence upon nonhuman offsprings' development // American Zoologist. Vol.25. P.911-923.

Yensen E. \& Sherman P.W. 2003. Ground squirrels (Spermophilus species and Ammospermophilus species) // Feldhammer G., Thompson B. \& Chapman J. (eds.). Wild mammals of North America. Baltimore: John Hopkins University Press. P.211-233.

Zhang J. \& Zhong W. 1981. On the colonial structure of Brandt's vole in burrow units // Acta Theriologica Sinica. Vol.1. P.51-56. 